\title{
Assessment of land use impact on hydraulic threshold conditions for gully head cut initiation
}

\author{
Aliakbar Nazari Samani ${ }^{1}$, Qiuwen Chen ${ }^{2,3}$, Shahram Khalighi ${ }^{1,3}$, Robert James Wasson ${ }^{4}$, and \\ Mohammad Reza Rahdari ${ }^{1}$ \\ ${ }^{1}$ Faculty of Natural Resources, University of Tehran, Karaj, Iran \\ ${ }^{2}$ CEER Nanjing Hydraulics Research Institute, Nanjing, 210023, China \\ ${ }^{3}$ RCEES Chinese Academy of Sciences, Beijing, 100085, China \\ ${ }^{4}$ Institute of Water Policy, National University of Singapore, Singapore \\ Correspondence to: Qiuwen Chen (qwchen@nhri.cn)
}

Received: 26 October 2015 - Published in Hydrol. Earth Syst. Sci. Discuss.: 18 January 2016

Accepted: 25 May 2016 - Published: 28 July 2016

\begin{abstract}
A gully as an accelerated erosion process is responsible for land degradation under various environmental conditions and has been known as a threshold phenomenon. Although the effects of gullying processes have been well documented, few soil erosion models have taken into account the threshold condition necessary for gully development. This research was devoted to determining the effects of land use change on hydraulic threshold condition and stream power of water flow through an in situ experimental flume $(15 \mathrm{~m} \times 0.4 \mathrm{~m})$. Results indicated that head cut initiation and detachment rates showed a better correlation to stream power indices than shear stress $\left(\tau_{\mathrm{cr}}\right)$. The threshold unit stream power value $\left(\omega_{\mathrm{u}}\right)$ for head cut initiation in rangeland, abandoned land, and dry farming land was 0.0276, 0.0149 , and $4.5 \times 10^{-5} \mathrm{~m} \mathrm{~s}^{-1}$, respectively. Moreover, the micro-relief condition of soil surface and surface vegetation affected the flow regime of discharge and velocity. It is seen that the composite hydraulic criteria of Froude number $(\mathrm{Fr})$ and discharge $(Q)$ can clearly discriminate the land uses' threshold. In fact, the remarkable decrease of $\tau_{\mathrm{cr}}$ in dry farming was related to the effect of tillage practice on soil susceptibility and aggregate strength. The findings indicated that using the unit steam power index instead of critical shear stress could increase the models' precision for prediction of head cut development. Compared to the Ephemeral Gully Erosion Model (EGEM) equation for critical shear stress, it is important to point out that for modelling of gully erosion, using single soil attributes can lead to an inaccurate estimation for $\tau_{\mathrm{cr}}$. In addition, based on the findings of this research, the use of
\end{abstract}

threshold values of $\tau_{\mathrm{cr}}=35 \mathrm{dyne}^{-2}$ and $\omega_{\mathrm{u}}=0.4 \mathrm{~cm} \mathrm{~s}^{-1}$ in physically based soil erosion models is susceptible to high uncertainty when assessing gully erosion.

\section{Introduction}

Gully erosion as an accelerated erosion phenomenon has been known as one of the most effective features in most landscapes. Non-linear dynamics and complexity of gully erosion have attracted great interest. Researchers have tried to establish different benchmarks to separate gullies from other concentrated water erosion features such as rills and streams. Critical cross-sectional area (Hauge, 1977) introduced a minimum width of $0.3 \mathrm{~m}$ and depth of $0.5 \mathrm{~m}$ (Brice, 1966) as a criterion to distinguish a rill from a gully (Imenson and Kwaad, 1980). Although the transition from rill to gully erosion is a continuum process, Torri et al. (1987) and Slattery and Bryon (1992) went a step further and suggested a hydraulic concept for rill and gully formation.

In fact the greatest proportion of sediment yield in a catchment scale is produced by gullies in a wide range of environmental conditions, as described by Nazari Samani et al. (2011) in Iran, Wasson et al. (1996) and Poesen et al. (2003) in Europe, and Li et al. (2003) in China. Many soil erosion models have tried to consider sheet and rill processes; however, fewer attempts have been made to take into account gully erosion at the catchment scale. 
The gullying process is an erosion phenomenon which can develop as soon as the determinant factors (e.g. overland flow and rainfall erosivity) exceed a threshold value or the resistance force (soil or vegetation) decreases to the critical point. The erosivity of run-off can be defined by hydraulic criteria such as boundary stream power, threshold velocity, or shear stress. The required threshold force value to create channelhead incision into the soil surface is mainly a function of soil and land use attributes. In addition, detailed investigation into the relationship between the topographic threshold and shear stress indicated that upslope catchment area and surface slope gradient are linked to stream power index and critical shear stress (Begin and Schumm, 1979). The potential of water flow for erosion can be obtained by combining hydraulic and topographic characteristics (Begin and Schumm, 1979; Conforti et al., 2011). Although the effects of land use on topographic threshold have been investigated (Vandekcheknov et al., 2000; Poesen et al., 2003; Nazari Samani et al., 2009), there is still great demand to understand head cut initiation and determine threshold hydraulic values when establishing a fundamental knowledge for soil erosion and developing a process-oriented gully erosion model. The key question is, how large should $\tau_{\mathrm{cr}}$ be in order to initiate a gully head cut? This question can be further divided into two criteria, namely shear stress and stream power.

Some researchers have investigated the hydraulic threshold of head cut initiation: Prosser et al. (1995) in the grassland near San Francisco, Prosser and Slade (1994) in southeastern Australia, Nachtergaele and Poesen (2002) in the Belgian loess belt, and Adelpour (2004) in loamy sands in Iran. However they suggested that more field-based experiments are necessary to effectively analyse effects of land use changes on the threshold situation of head cut initiation. In addition, most physically based erosion models such as WEPP, CREAMS, and PRORILL are based on the simplified transport capacity equation (Yalin, 1977) and soil detachment rate as well as shear stress (Zhang et al., 2014). These models predict the soil erosion through the rill and inter-rill concept while neglecting gully erosion distribution along a catchment. Meanwhile, it is essential to study the hydraulic thresholds under different environmental conditions and land use patterns when establishing a worldwide model for comprehensive erosion predication.

This objectives of this study were to (1) understand the land use effects on head cut initiation, (2) reveal the relationship between head cut detachment and hydraulic threshold indices (stream power and shear stress), and (3) identify the most determinant factor for gully and concentrated flow erosion.

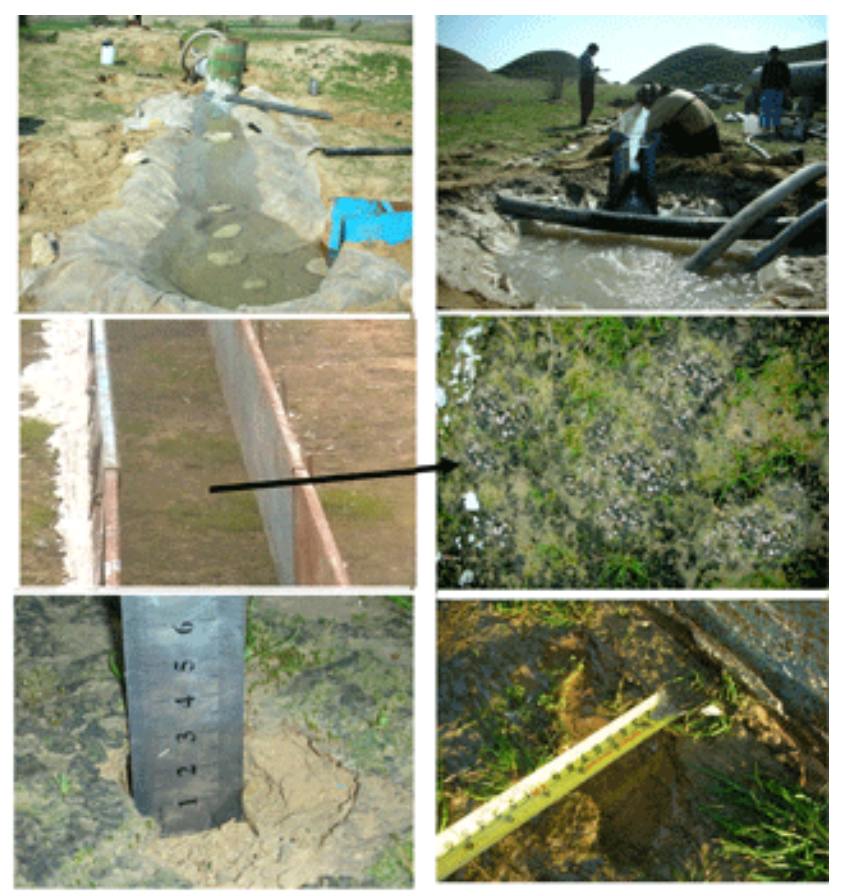

Figure 1. Flume, water supply, retention pond, overflow pipe, and Parshall flume (top photos); flume surface and vegetation (grass and pale pink lichen patch) in the rangeland (middle photos); sample of initiated head cut with height of $3 \mathrm{~cm}$ in rangeland (bottom left photo); and abandoned land (bottom right photo).

\section{Materials and methods}

\subsection{Experiment design}

The experiments were conducted in the Samal area located in the Dareh-Kore watershed of Boushehr province in the south of Iran. The region has a typical arid to semi-arid climate with an average annual temperature of $14^{\circ} \mathrm{C}$ and an average annual rainfall of $200 \mathrm{~mm}$. The main lithological formations include the Miocene Fars Group (Aghajari, Mishan; consisting of marl, shale, and marly and shaly limestone) in the uplands and Quaternary alluvium (consisting of gravels, sands, silt, and clay) in the piedmont plain. Gully erosion and bad land formation are two highly destructive processes impacting on the hilly and lowland areas, and are common on the Quaternary formations with slope gradients of less than $20 \%$.

The flume experiments were conducted using an erosion plot that was $15 \mathrm{~m}$ long, $0.4 \mathrm{~m}$ wide, and $0.5 \mathrm{~m}$ high, designed to create non-uniform flow resistance. The ground surface cover of the soil was not disturbed. For each experiment, the parameters of hydraulic flow were measured over the $9 \mathrm{~m}$ reach in the middle of the flume (Figs. 1 and 2). Three land uses - dry farming land, rangeland, and abandoned areas were chosen. In addition, in order to prevent the effects of spatial variation of soil properties, all tests were conducted 
Table 1. Soil attributes of three land uses selected for experiments.

\begin{tabular}{llllllllllll}
\hline Land use & Texture & $\begin{array}{l}\text { Silt } \\
(\%)\end{array}$ & $\begin{array}{c}\text { Ec } \\
\left(\mathrm{ds} \mathrm{m}^{-1}\right)\end{array}$ & $\begin{array}{c}\mathrm{OC} \\
(\%)\end{array}$ & $\begin{array}{c}\text { Lime } \\
(\%)\end{array}$ & $\begin{array}{l}\mathrm{Na} \\
(\mathrm{meq} / \mathrm{lit})\end{array}$ & $\begin{array}{l}\mathrm{Ca} \\
(\mathrm{meq} / \mathrm{lit})\end{array}$ & SAR & $\begin{array}{c}\mathrm{pH} \\
\begin{array}{c}\mathrm{Cl} \\
(\mathrm{meq} / \mathrm{lit})\end{array}\end{array}$ & $\begin{array}{l}\mathrm{Ground} \\
\text { slope } \\
(\%)\end{array}$ \\
\hline Rangeland & Sandy loam & 8 & 3.74 & 0.44 & 23.30 & 33 & 18.4 & 7.8 & 7.3 & 15.6 & 5.9 \\
Dry farming & Sandy loam & 5.5 & 3.44 & 0.85 & 23.75 & 34 & 15 & 8.1 & 7.3 & 16.4 & 0.13 \\
Abandoned & Sandy loam & 5 & 3.34 & 0.50 & 21.25 & 29.5 & 14 & 7 & 7.3 & 14.7 & 4.4 \\
\hline
\end{tabular}

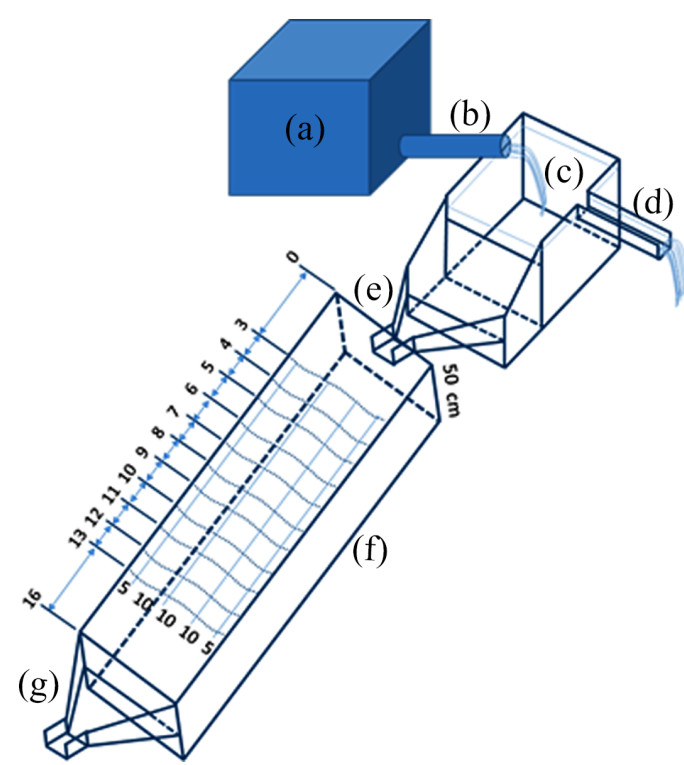

Figure 2. Schematic of experimental flume. (a) Main water supply; (b) input of stilling pond; (c) small retention pond; (d) overflow spillway for constant levelling; (e) inlet Parshall flume; (f) midsection mesh used to measure flow depth and ground elevation; (g) outlet Parshall flume.

at a site consisting of three land uses. The distance between test locations was about $200 \mathrm{~m}$. The soil attributes according to the land use are presented in Table 1, which show that no significant difference was found between the soil attributes, although a small variation in the samples could be seen in the $\mathrm{Ca}$, organic matter, and $\mathrm{Na}$. However, the slope could not be held constant. The maximum soil surface slope was in the rangeland (5.9\%), while the dry farming land had the least surface slope $(0.13 \%)$. Therefore, in order to determine the effect of land slope, the shear stress index was used. This index considers both discharge and energy characteristics, which are explained further in the following section. The characteristics of the land cover in the experimental sites were as follows:

a. Rangelands: no surface gravel and uniform cover of lichens and mosses (Fig. 1), with grasses (5\%) of Stipa capensis, Stipa arabica, and low litter (1\%). b. Dry farming: ground cover of annual grasses (Hordeum sp.; Bromus tectorum), forbs (40\%) (Chenopodium album, Astragalus spp.), and residuals of stalks from previous years, and no surface gravel. In contrast to rangelands, the canopy cover of the dry farming land is much greater because of agriculture operations and low slope as well as establishment of weeds.

c. Abandoned areas: this land had been relinquished for 7 years. Vegetation cover of $50 \%$ includes annual grasses (Aegilops sp., Bromus tectorum) and forbs ( $F u$ maria asepala; Alhagi camelorum), low gravel cover $(1 \%)$, and litter $(3 \%)$.

\subsection{Experimental operation, measurement, and parameter calculation}

The flume's sidewalls were beaten into the soil and sealed with plaster, cement, and soil to prevent leakage and incursions by animals. To determine the slope of the longitudinal profile with high precision, ground surveying was performed using a theodolite camera, levelling rod, and measuring tape. After setting up the water supply equipment including a water tank, stilling basin, and Parshall flume at both ends of the plot, the surface of flume was wetted carefully by a hand sprinkler. The experiment was started with very low discharge $\left(0.75 \mathrm{~L} \mathrm{~s}^{-1}\right)$, and after each run the discharge was increased. The total number of experiments in dry farming land, abandoned land, and rangeland were seven, five, and four, respectively. The numbers of runs were different because head cut initiation in different land uses was not similar, and the tests were continued until the threshold condition was reached.

The experiments were done under a steady condition, meaning that the discharge was constant in each replicate, and in the consecutive test the discharge was increased. The input discharge was controlled to be constant by a series of pond and storage and a small spill way. The water supply and discharge controller pond were placed at the beginning of the inlet before water began flowing into the Parshall flume.

For every test, the flow parameters including discharge, depth of flow (by a steel ruler), and sediment samples (at the end of the flume) were measured directly, while the water surface velocity was determined by liquid dye tracers (injected once). The soil surface of plots was delaminated and 
monitored by photos. Any ditch or step-like incised erosion feature with a size over $3 \times 3 \mathrm{~cm}$ was considered as a head cut generation. The experiments were implemented step by step, and after each run the flume was examined for head cut initiation. Through such a procedure, the head cut initiation and development could be observed.

The following relations were used to calculate the hydraulic characteristics of flow.

Mean flow velocity: $V=\frac{Q}{A}$

Shear stress of flow : $\tau=\gamma R S$

Stream power : $\omega=\tau V=g d S V$

Total stream power : $\omega_{T}=\rho_{\mathrm{g}} Q S$

Unit stream power : $\omega_{\mathrm{u}}=S V$

The soil detachment rate : $D_{\mathrm{r}}=\frac{C_{V} \cdot Q \cdot t}{6}$

$Q$ is discharge $\left(\mathrm{m}^{3} \mathrm{~s}^{-1}\right) ; A$ is cross-section area of flow $\left(\mathrm{m}^{2}\right)$; $V$ is flow velocity $\left(\mathrm{m} \mathrm{s}^{-1}\right) ; d$ is flow depth $(\mathrm{m}) ; v$ is kinematic viscosity $\left(v=0.01 \mathrm{~cm}^{2} \mathrm{~s}^{-1}\right) ; g$ is gravitational acceleration $\left(\mathrm{m} \mathrm{s}^{-2}\right) ; \gamma$ is specific gravity $\left(\rho_{\mathrm{g}}\right) ; S$ is water surface slope; $R$ is hydraulic radius (m); $C_{V}$ is sediment weight concentration $\left(\mathrm{kg} \mathrm{m}^{3}\right)$; and $t$ is run time (s). The flow regime was determined based on the Froude number equation $(F r)$.

The basic assumption for this experiment is that the detachment and head cut initiation by water flow occurs when the run-off energy is as large as the soil particle resistance. The validity and generality of this assumption have been verified by previous studies (Yang, 1996; Knapen et al., 2007). The threshold value was calculated based on the Foster (1982) approach through fitting the line of $D_{\mathrm{r}}$ to stream power $(\omega)$ and shear stress (Eq. 1)

$D_{\mathrm{r}}=K_{\mathrm{c}} \omega+b$,

where $D_{\mathrm{r}}$ is the detachment rate of flow $\left(\mathrm{kg} \mathrm{m}^{-2} \mathrm{~s}^{-1}\right)$ and $\omega$ is stream power (Eqs. 3-6). $K_{\mathrm{c}}$ and $b$ are the regression parameters.

To find the effect of land use on flow characteristic condition, the measured detachment rates $\left(D_{\mathrm{r}}\right)$ from experimental tests were plotted versus hydraulic indices $\left(\omega_{\mathrm{u}}, \omega_{T}, \omega\right.$, and $\tau)$. According to the slope of fitted lines, the effects of land use on water flow were assessed.

To compare the findings with a gully erosion model, the procedure of the Ephemeral Gully Erosion Model (EGEM) for critical hydraulic shear stress (Tekwa et al., 2015) was calculated based on Eq. (8).

$\tau_{\mathrm{cr}}=0.0065 \cdot\left(\%\right.$ Clay $\left.\times 10^{0.0182}\right)$
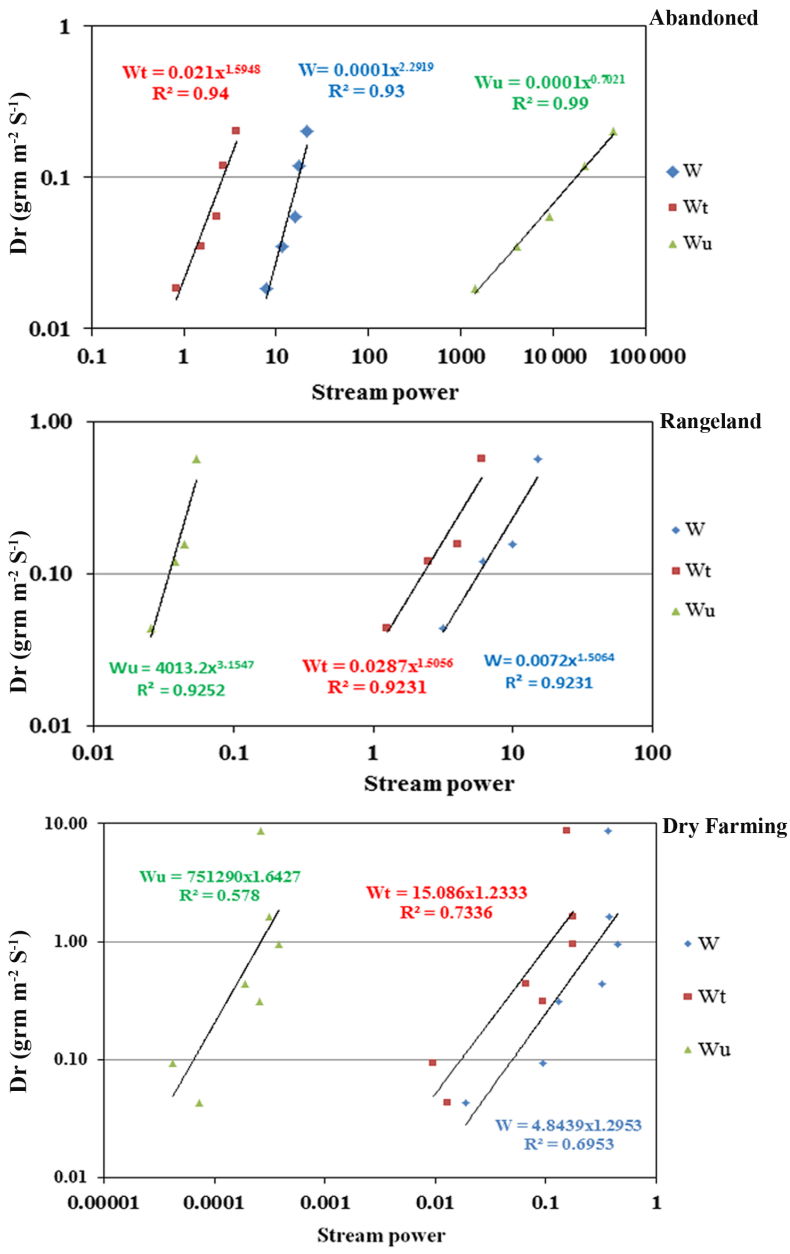

Figure 3. Relationship between stream power indices and detachment rate in different land uses $(P<0.001)$.

\section{Results}

\subsection{Effects of land use on stream power and flow type}

Results of calculated stream power and their relations to detachment rate $\left(D_{\mathrm{r}}\right)$ of all land uses were shown in Fig. 3. The comparison of $D_{\mathrm{r}}$ indicated significant differences of sediment load between three land uses. The parameters of the regression lines (slope and intercept) did not follow the same trend in all land uses and indices. Dry farming land showed the smallest values of total stream power indices, while rangeland and abandoned lands had the smallest value of unit stream power $\left(\omega_{\mathrm{u}}\right)$. Although all stream power indices could indicate erosion potentials, $\omega_{\mathrm{u}}$ had the highest significant $(p<0.01)$ values $\left(R^{2}=0.99\right)$ based on the coefficient of determination. However, the cloud of points for dry farming land exhibited a scattered pattern, which may be explained by the disturbance in agricultural lands.

The Froude number $(F r)$ varied from 0.05 to 5.1, and the head cut features developed under sub-critical to super- 


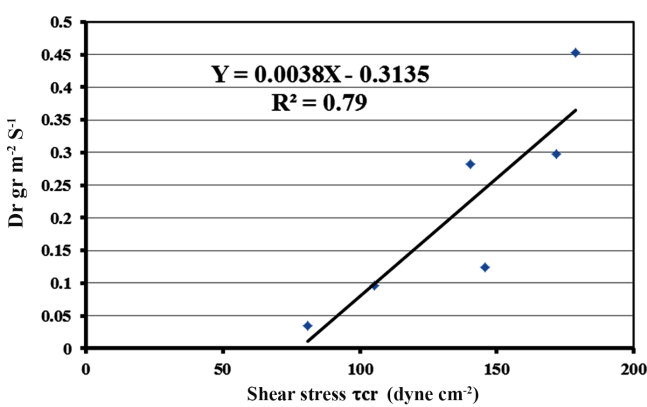

Figure 4. Relationship between shear stress $(\tau)$ and detachment rate in the rangeland $(P<0.01)$

critical conditions. The lowest $\mathrm{Fr}$ values for head cut initiation were 1.61 (with $Q=9.2 \mathrm{~L} \mathrm{~s}^{-1}$ ) for rangeland and 0.1 (with $Q=8.2 \mathrm{~L} \mathrm{~s}^{-1}$ ) for dry farming land. The discharge for both dry farming land and rangeland were similar, but the flow types were quite different due to soil disturbance in dry farming land. Therefore, it is expected that, by coupling $\mathrm{Fr}$ value and flow rate, a composite parameters for head cut initiation could be more meaningful.

\subsection{Impact of land use on the threshold shear stress for surface erosion}

The results of the relationship between the detachment rate $\left(D_{\mathrm{r}}\right)$ and the shear stress are shown in Figs. 4-6. We preferred to use dyne per square centimetre $\left(\right.$ dyne $\left.\mathrm{cm}^{-2}\right)$ as the shear stress unit because of the small values obtained in units of pascal $\left(1 \mathrm{~Pa}=10\right.$ dyne $\left.\mathrm{cm}^{-2}\right)$. The significant relationships $(P=0.05)$ between $\operatorname{Dr}$ and shear stress were observed. The threshold shear stress for each land use was calculated based on the slopes and intercepts shown in Figs. 46 . These values are 83,11 , and $74 \mathrm{dyne} \mathrm{cm}^{-2}$ for rangelands, dry farming lands, and abandoned areas, respectively. Moreover, soil resistance to concentrated overland flow $\left(K_{\mathrm{c}}\right)$ was obtained for rangeland (0.0038) and dry farming (0.1912). It is notable that the resistance of soil to concentrated flow in rangelands is more than 50 times that in dry farming land.

Through Eq. (8), the critical shear stress $\tau_{\text {cr }}$ for dry farming land, rangeland, and abandoned land was calculated to be $7.53,6.43$, and 8.40 dyne $\mathrm{cm}^{-2}$, respectively. The differences between field data and EGEM were remarkably high. Such inconsistency revealed that the method of estimating $\tau_{\text {cr }}$ based on a single soil attribute could cause unreliable results.

\subsection{Effect of land use type on gully initiation threshold}

The numbers of head cuts corresponding to mean shear stress for each experiment were listed in Table 2 . The critical shear stress for head cut initiation was $174 \mathrm{dyne}^{-2}$ in rangeland, 35 dyne $\mathrm{cm}^{-2}$ in dry farming land, and 153 dyne $\mathrm{cm}^{-2}$ in abandoned land. The three-four-fold difference between the calculated critical shear stresses in the three studied land

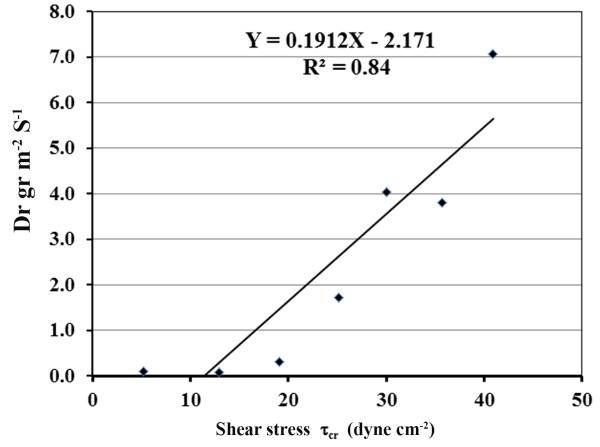

Figure 5. Relationship between shear stress $(\tau)$ and detachment rate in dry farming land $(P<0.05)$.

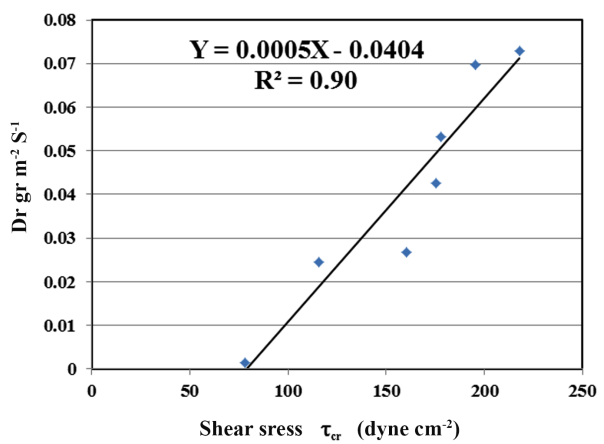

Figure 6. Relationship between shear stress $(\tau)$ and detachment rate in abandoned land $(P<0.001)$.

uses could be linked to the soil surface condition. Although the vegetation cover of rangeland was less than that of dry farming land, the biological crust of lichens and mosses made the soil very resistant to detachment. In fact, the presence of biological crusts on the surface of the soil in the rangeland increased the surface soil resistance several-fold (Table 2, Figs. 4 and 5). Table 2 demonstrates that the number of head cuts increased with shear stress. For example, from run 3 to run 5 in abandoned land, the number of head cuts increased more than two-fold, while the average shear stress increased just 1.3 times.

From Table 2 and Fig. 6, it can be found that the relationship between head cuts and shear stress of abandoned land was similar to the dry farming lands, although the critical shear stress for head cut initiation of abandoned land (153 dyne $\mathrm{cm}^{-2}$ ) was close to that of rangeland (174 dyne $\mathrm{cm}^{-2}$ ).

\section{Discussion}

From the study, it was found that, for the rangeland with no disturbance on soil and cover, both detachment and gully head initiated within a sub-critical flow regime. The threshold value of $F r$ varied from 0.65 to 1.10 . This variation is 
Table 2. Shear stress for different runs with observed head cuts for each land use $\left(1 \mathrm{~Pa}=10\right.$ dyne $\left.\mathrm{cm}^{-2}\right)$.

\begin{tabular}{|c|c|c|c|c|}
\hline Land use & Run & $\begin{array}{r}\text { Mean shear } \\
\text { stress along } \\
\text { the flume } \\
\left(\text { dyne } \mathrm{cm}^{-2} \text { ) }\right.\end{array}$ & $\begin{array}{l}\text { Number of } \\
\text { head cut } \\
\text { initiations }\end{array}$ & $\begin{array}{r}\text { Critical shear } \\
\text { stress for } \\
\text { head cut } \\
\left(\text { dyne } \mathrm{cm}^{-2}\right)\end{array}$ \\
\hline \multirow{4}{*}{ Rangelands } & 1 & 70 & - & \multirow{4}{*}{174} \\
\hline & 2 & 106 & - & \\
\hline & 3 & 146 & 1 & \\
\hline & 4 & 178 & 2 & \\
\hline \multirow{7}{*}{ Dry farming land } & 1 & 5 & - & \multirow{7}{*}{35} \\
\hline & 2 & 9 & - & \\
\hline & 3 & 15 & - & \\
\hline & 4 & 19 & - & \\
\hline & 5 & 34 & 2 & \\
\hline & 6 & 40 & 4 & \\
\hline & 7 & 42 & 5 & \\
\hline \multirow{5}{*}{ Abandoned areas } & 1 & 78 & \multirow{5}{*}{-153} & \\
\hline & 2 & 115 & & \\
\hline & 3 & 161 & & \\
\hline & 4 & 178 & & \\
\hline & 5 & 217 & & \\
\hline
\end{tabular}

confirmed by other studies that reported the $F r$ number in the range of $0.5-2.8$ as a threshold value for water flow incision (Knapen et al., 2007; Thonon, 1999; Adelpour, 2004; Prosser et al., 1995). One possible explanation for the development of head cut under low Fr number in dry farming land might be the high ground vegetation and micro-relief roughness. However, tillage operations and soil disturbances significantly increased the instability and erodibility of soil aggregates; consequently, flow detached and entrained soil particles more easily, which led to the creation of head cuts. Despite sub-critical flow in abandoned and dry farming lands, the detachment rate was more than twice that of rangeland. This could be attributed to the decrease in aggregate resistance produced by tillage operations (Knapen et al., 2007; West et al., 1992).

Flow discharge and $\mathrm{Fr}$ can be used as a composite parameter for discriminant of surface erosion and head cut initiation. The values of this composite parameter $(Q \cdot F r)$ were 14.81 , 0.81 , and 2.58 for rangeland, abandoned land, and dry farming land, respectively. It can be seen that the composite parameter could clearly rank the flow energy of the three land uses. Therefore, in arid and semi-arid regions with sparse and low vegetation cover, any decreasing of vegetation cover could strongly affect the surface roughness and flow regime, and consequently the soil detachment and erosion (Léonard and Richard, 2004). This finding indicated that the effects of land disturbances and land cover changes on hydraulic threshold of soil detachment and gully erosion were significant, which may not be resilient on a short timescale.

The threshold values for unit stream power $\left(\omega_{\mathrm{u}}\right)$ were $0.0276,0.0149$ and $4.48 \times 10^{-5} \mathrm{~m} \mathrm{~s}^{-1}$ for rangeland, abandoned land, and dry farming land, respectively. The 100fold differences could be attributed to the land use effects on water flow energy and the tillage operation effects on soil erodibility. In the EUROSEM model, $\omega_{\mathrm{u}}$ was assumed to be $0.4 \mathrm{~cm} \mathrm{~s}^{-1}$, which is not consistent with our findings. The scattered pattern for dry farming land indicated that, when the detachment rate was higher than $1\left(\mathrm{~kg} \mathrm{~m}^{-2} \mathrm{~s}^{-1}\right)$, the model prediction was not accurate enough (Fig. 3).

The relationship between average shear stress, contributory catchment area, and slope proposed by Begin and Schumm (1979) showed the role of a geomorphic threshold on shear stress. Based on the relationship, it is seen that, as $\tau_{\text {cr }}$ increases, upslope area and slope gradient must increase in order to initiate a gully. Nazari Samani et al. (2009) reported that in this study area, when land use changed from rangeland to dry farming land, the areas susceptible to gullying increased by a factor of 2 , from 6 to $12 \%$ of the total area. Therefore, land use changes not only affected soil stability but also decreased the geomorphic threshold, causing more areas to be prone to gullying.

In addition, the impacts of tillage operations on the aggregate attributes such as degree of consolidation, soil weathering, dryness, and wetness can affect the erodibility parameter $K_{\mathrm{r}}$ (Franti et al., 1985; King et al., 1995). This study showed that land use change could increase soil erodibility more than 50 times and decrease boundary shear stress about 6 fold. This meant that the effect of land use change on $K_{\mathrm{r}}$ was more significant than on $\tau_{\mathrm{cr}}$. Similar results have been reported by other researchers (Nachtergaele and Poeson, 2002; Knapen et al., 2007), who found that using the conventional $K$ in the USLE cannot reflect the spatial variations of erodibility on a landscape scale. With the same soil attributes, both the vegetation cover and the micro-relief of the ground surface are the main factors determining the spatial variation of detachment and sedimentation along the flume (Bergsma and Farshand, 2007), preventing the establishment of a stable and uniform erosion pattern. To assess and model erosion over a landscape, a simple sediment transport equation does not give a precise result regarding detachment and sedimentation (Morgan, 2005; Adelpour, 2004). Therefore, the adoption of a large range of $K_{\mathrm{r}}$ values is essential to improve physically based erosion models.

It was noticeable that $K_{\mathrm{r}}$ of the abandoned land and rangeland were similar in low run-off depth (run 1 and 2 in Table 2). However, $K_{\mathrm{r}}$ of the abandoned land in high run-off depth (run 3 in Table 2) was different from that of the rangeland, while it was similar to that of the dry farming land. Such behaviour indicated that for a given soil a change of land use affected the run-off erosion process for several years. The value of $\tau_{\mathrm{cr}}$ for head cut initiation on the rangeland is 5 times higher than that in dry farming land, implying that high surface and subsurface $(10 \mathrm{~cm})$ aggregate resistance in the rangeland was probably a result of the biological crust.

The mean $\tau_{\text {cr }}$ for the whole dataset of this research was 134 dyne $\mathrm{cm}^{-2}$, which was lower than the global average 
value of 150 dyne $\mathrm{cm}^{02}$ (Knapen et al., 2007). The main reason for this difference could be the discrepancy of ground features and the use of a sandy loam soil. The large differences between $\tau_{\mathrm{cr}}$ in this research and the result (mean of 7.45 dyne $\mathrm{cm}^{-2}$ ) obtained by the EGEM formula (Tekwa et al., 2015) implied that the application of the EGEM formula to predicting of gully head cut initiation and gully sediment yield cannot be satisfactory. Previous research (Nachtargale, 2001) held the similar opinion. The main reasons could be the inverse relation of erodibility to $\tau_{\mathrm{cr}}$ and the use of a simple soil attribute (clay content) for estimation of threshold shear stress in EGEM.

The relationships between the numbers of observed head cuts and shear stress in the abandoned area and rangeland were the same when $\tau_{\mathrm{cr}}<140$ dyne $\mathrm{cm}^{-2}$. However, in abandoned land, as the $\tau_{\mathrm{cr}}$ increased, the observed number of head cuts increased by a factor of 3 (Table 2). This was because land use not only affected the resistance of the surface soil but also affected the resistance of the sub-soil. After 7 years of abandonment, the erodibility of sub-soil had not changed significantly. Even though no tillage operations had been conducted on the abandoned land for 7 years, the subsoil had not returned or even could not return to its original condition and level of resistance.

In most physically based and process-based models, $D_{\mathrm{r}}$ is dominated by the shear stress. The regression results of detachment rate $\left(D_{\mathrm{r}}\right)$ in this study showed that close relations between $D_{\mathrm{r}}$ and $\omega_{\mathrm{u}}$ existed not only in head cut erosion but also in surface and inter-rill erosion. Such validity and generality of power concept for erosion modelling could be related to the fact that all of stream power indices have been derived from the basic concepts of fluid mechanics (Yang, 1996). Many other studies (in situ and in vitro) have also shown that stream power is better than other parameters. Although the hydraulic and erodibility values in this study were within the range of the reported values by the previous studies (Nearing et al., 1999; Knapen et al., 2007; Zhang et al., 2014), the erodibility and threshold values of unit stream power had not been confirmed by the WEPP, EUROSEM, and EGEM models (Zhang et al., 2003, 2014; Tekwa et al., 2015). Together with previous findings (Zhang et al., 2003, 2014), it is claimed that more efforts should be made to further investigate the mechanisms of soil erosion and improve erosion models.

\section{Conclusions}

Experimental results of detachment and head cut initiation indicated that critical shear stress $\left(\tau_{\mathrm{cr}}\right)$, soil resistance to concentrated flow $\left(K_{\mathrm{c}}\right)$, and head cut initiation were dependent on land use and soil surface conditions. Critical shear stress has been the most widely used parameter for physically based models. This study showed that most physically based models should use a wider range of both $K_{\mathrm{r}}$ and $\tau_{\mathrm{cr}}$ values. In other words, the use of a single value of $\tau_{\mathrm{cr}}=35$ dyne $\mathrm{cm}^{-2}$ or $\omega_{\mathrm{u}}=0.4 \mathrm{~cm} \mathrm{~s}^{-1}$ as the threshold hydraulic parameters cannot accurately represent the threshold condition for gully initiation. In addition, the duration of farming land abandonment should be taken into consideration in order to obtain a realistic value for $K_{\mathrm{r}}$.

This study also indicated that more efforts should be made to obtain a closer insight on the soil erosion mechanisms and erosion modelling. In many physically based and processbased models, $D_{\mathrm{r}}$ is dominated by the shear stress; however, the findings of this research revealed that the unit stream power showed stronger correlation to detachment rate. Therefore, a new approach based on the stream power concept should be considered when developing a processbased model for gully head cut erosion.

Acknowledgements. This research was supported by the Centre of Excellence for Sustainable Watershed Management of the University of Tehran and the National Nature Science Foundation of China (51425902). We appreciate Catherine Rice, $\mathrm{PhD}$, from Purdue University, USA for proofreading the English. The authors would like to thank the anonymous reviewers for their valuable and helpful comments.

Edited by: Y. Chen

\section{References}

Adelpour, A. A.: An investigation and hydrological thresholds of channel erosion in different landuse with loamy-sand soil, $\mathrm{PhD}$ dissertation, Shahid Chamran University of Ahvaz, Ahvaz, 2004.

Begin, Z. B. and Schumm, S. A.: Instability of alluvial valley floors: a method for its assessment, T. ASAE 22, 347-350, 1979.

Bergesma, E. and Farshad, A.: Monitoring erosion using micro topographic features, in: Monitoring and evaluation of Soil Conservation and Watershed Development Projects, edited by: d. Graaff, J., Cameron, J., Sombatpanit, S., Pieri, C., and Woodhill, J., Scinece Publishers, India, 249-266, 2007.

Brice, J. B.: Erosion and deposition in the loess-mantled Great Plains, medecine creek drainage basin, US Geological Survey Professional Paper 352H, US Geological Survey, Washington, USA, 235-339, 1966.

Conforti, M., Aucelli, P. P. C., Robustelli, G., and Scarciglia, F.: Geomorphology and GIS analysis for mapping gully erosion susceptibility in the Turbolo stream catchment (Northern Calabria, Italy), Nat. Hazards, 56, 881-898, 2011.

Foster, G. R.: Modeling the erosion process, in: Hydrologic Modeling of Small Watersheds, edited by: Hahn, C. T., American Society of Agricultural Engineering, Michigan, USA, 295-380, 1982.

Franti, F. G., Laflen, J. M., and Watson, D. A.: Soil erodibility and critical shear under concentrated flow, ASAE Paper 85-2033, ASAE, 1985.

Franti, T. G., Laflen, J. M., and Watson, D. A.: Predicting soil detachment from high discharge concentrated flow, T. ASAE, 42, 329-335, 1999. 
Hauge, C.: Soil erosion definitions, Calif. Geol., 30, 202-203, 1977.

Imeson, A. C. and Kwaad, F. J. P. M.: Gully types and gully prediction, KNAG Geografisch Tijdschrift XIV, 5, 430-441, 1980.

King, K. W., Flanagan, D. C., Norton, L. D., and Laflen, J. M.: Rill erodibility parameters influenced by long-term management practices, T. ASAE, 38, 159-164, 1995.

Knapen, A., Poesen, J., Govers, G., Gyssels, G., and Nechtergaele, J.: Resistance of soils to concentrated flow erosion: A review, Earth-Sci. Rev., 80, 75-109, 2007.

Léonard, J. and Richard, G.: Estimation of runoff critical shear stress for soil erosion from soil shears strength, Catena, 57, 233249, 2004

Li,Y., Poesen, J., Yang, J. C., Fu, B., and Zhang, J. H.: Evaluating gully erosion using $137 \mathrm{Cs}$ and $210 \mathrm{~Pb} / 137 \mathrm{Cs}$ ratio in a reservoir catchment, Soil Till. Res., 69, 107-115, 2003.

Morgan, R. P. C.: Soil erosion and conservation, 3rd Edn., Blackwell, UK, p. 316, 2005.

Nachtergaele, J. and Poesen, J.: Spatial and temporal variations in resistance of loess-derived soils to ephemeral gully erosion, Eur. J. Soil Sci., 53, 449-463, 2002.

Nachtergaele, J.: A Spatial and Temporal Analysis of the Characteristics, Importance and Prediction of Ephemeral Gully Erosion, PhD Thesis, Department of Geography - Geology, Catholic University of Leuven, Belgium, 2001.

Nachtergaele, J., Poesen, J., Vandekerckhove, L., Oostwoud Wijdenes, D., and Roxo, M.: Testing the Ephemeral Gully Erosion Model (EGEM) for two Mediterranean environments, Earth Surf. Proc. Land., 26, 17-30, 2001.

Nazari Samani, A., Ahmadi, H., Jafari, M., Guy, B., Ghoddousi, J., and Malekian, A.: Geomorphic threshold conditions for gully erosion in southwestern Iran (Boushehr-Samal watershed), J. Asian Earth Sci., 35, 180-189, 2009.

Nazari Samani, A., Wasson, R. J., and Malekian, A.: Application of multiple sediment fingerprinting techniques to determine the sediment source contribution of gully erosion: Review and case study from Boushehr province, south-western Iran, Prog. Phys. Geogr., 35, 375-391, 2011.

Nearing, M. A., Simanton, J. R., Norton, L. D., Bulygin, S. J., and Stone, J.: Soil erosion by surface water flow on a stony, semiarid hill-slope, Earth Surf. Proc. Land., 24, 677-686, 1999.
Poesen, J., Nachtergaele, J., Verstraeten, G., and Valentin, C.: Gully erosion and environment change: importance and research needs, Catena, 50, 91-133, 2003.

Prosser, I. P. and Slade, J.: Gully formation and the role of valleyfloor vegetation, Geology, 22, 1127-1136, 1994.

Prosser, I. P., Dietrich, W. E., and Stevenson, J.: Flow resistance and sediment transport by concentrated overland flow in a grassland valley, Geomorphology, 13, 73-86, 1995.

Slattery, M. C. and Bryan, R. B.: Hydraulic conditions for rill incision under simulated rainfall. A laboratory experiment, Earth Surf. Proc. Land., 17, 127-146, 1992.

Tekwa, I. J., Laflen, J. M., and Kundiri, A. M.: Efficiency test of adapted EGEM model in predicting ephemeral gully erosion around Mubi, Northeast Nigeria, Int. Soil Water Conserv. Res., 3, 15-27, 2015.

Thonon, I.: Thresholds for incipient rilling and particle entrainment, Faculty of Geographical Sciences, Utrecht University, Utrecht, 1999.

Torri, D., Dfalanga, M., and Chisci, G.: Threshold conditions for incipient rilling, Catena, 8, 97-105, 1987.

Vandekerckhove, L., Poesen, J., Oostwoud Wijdenes, D., Nachtergaele, J., Kosmas, C., Roxo, M. J., and Figueiredo, T. D. E. Thresholds for gully initiation and sedimentation in Mediterranean Europe, Earth Surf. Proc. Land., 25, 1201-1220, 2000.

Wasson, R. J, Olive, L. J., and Rosewell, C. J.: Rates of erosion and sediment transport in Australia, IAHS Publ., 236, 139-148, 1996.

West, L. T., Miller, W. P., Bruce, R. R., Langdale, G. W., Laflen, J. M., and Thomas, A. W.: Cropping system and consolidation effects on rill erosion in the Georgia Piedmont, Soil Sci. Soc. Am. J., 56, 1238-1243, 1992.

Yalin, M. S.: Mechanics of Sediment Transport, Pergamon Press, Oxford, 298 pp., 1977.

Yang, C. T.: Sediment Transport, Theory and practices, McGraw Hill, New York, 396 pp., 1996.

Zhang, G., Liu, B., Liu, G., He, X., and Nearing, M. A.: Detachment of undisturbed soil by shallow flow, Soil Sci. Soc. Am. J., 67, 713-719, 2003.

Zhang, Q., Dong, Y., Li, F., Zhang, A., and Lei, T.: Quantifying detachment rate of eroding rill or ephemeral gully for WEPP with flume experiments, J. Hydrol., 519, 2012-2019, 2014. 